\title{
A LOCAL GOVERNMENT REVENUE SYSTEM UNDER MACROECONOMIC PRESSURE: THE CASE OF POLAND
}

\section{Beata Guziejewska, Katarzyna Walerysiak-Grzechowska*}

\begin{abstract}
This study analyses macroeconomic factors, especially the level of GDP and its changes, in terms of their impact on the revenues of Polish local governments from 1999 to 2016. The importance of the factors in managing local finances is growing because of the increasing threats of globalisation and economies becoming more vulnerable to exogenous shocks. This article attempts to identify the structural weaknesses of the local government revenue system in Poland in the context of macroeconomic circumstances. It follows from our research that the property tax and general state grants are relatively insensitive to GDP changes and that they are capable of ensuring local revenue stability during a crisis. Greater sensitivity to economic fluctuations is shown by shared income taxes. The study analyses Central Statistical Office and Eurostat data using an advanced research approach, the key elements of which are cointegration analysis and a vector error correction model.
\end{abstract}

Keywords: local government revenue system, fiscal decentralisation, local taxes, grants JEL Classification: H70, H71, H77

\section{Introduction}

Both theoreticians and practitioners have long shown interest in constructing an optimal system for financing local governments, because of its vital importance for the economy and society. The focus of the great majority of studies analysing local finances has been on local governments' financial independence (fiscal autonomy) and the effective financing

* Beata Guziejewska, University of Lodz, Lodz, Poland (beata.guziejewska@uni.lodz.pl);

Katarzyna Walerysiak-Grzechowska, University of Lodz, Lodz, Poland

(katarzyna.walerysiak@uni.lodz.pl).

The authors wish to thank the anonymous referee for their valuable comments and suggestions, which helped them improve the quality of the manuscript. They also gratefully acknowledge the assistance and comments from Wojciech Grabowski, PhD, Chair of Econometric Models and Forecasts, University of Lodz. 
of tasks assigned to different levels of government. In the wake of the global financial crisis of 2007-2008, macroeconomic circumstances were added to intergovernmental fiscal relations as a factor determining the financial situation of local governments.

The main sources of revenue for local governments include own revenues, general state grants and specific state grants. According to Polish law, own revenues consist of local taxes (mainly the property tax), local charges and shared taxes (local portions of personal income tax (PIT) and corporate income tax (CIT) collected by the state). General state grants are block grants that local governments can spend as they deem appropriate, as opposed to specific state grants, the use of which is restricted to financing specific services and controlled by the central government.

Given that municipalities must finance public goods that are vital to the daily lives of all residents, an optimal financial system should ensure the adequacy of their revenues, as well as protecting them against potentially adverse impacts from the economic cycle.

Although the doctrine emphasises that the purpose behind general state grants is to equalise and stabilise local revenues, only a few studies so far have taken an interest in investigating local funding sources with respect to economic cycle fluctuations. This study has been specifically designed to fill this gap. The established theories recommending local governments to diversify the sources of local revenues sometimes omit the fact that individual types of revenues are differently affected (in depth and extent) by GDP fluctuations, and that local governments have neither the means nor the ability to respond to the overall macroeconomic situation. It is for the apparent gap in research that in this study the financial independence of local governments is analysed over a longer time horizon and, most importantly, in the context of macroeconomic circumstances.

\section{Special Character of Local Finances}

Local government finances are not autonomous in the sense that they constitute an element (subsector) of a country's public financial system. The external environment in which local governments implement their budget policies owes its volatility to two factors that shape and influence the policies. One is the legislative activity of the state, which establishes the legal, financial and institutional framework for local governments. Regrettably, the dominant position of the state is associated with its notorious practice of having local governments pay the costs of the public sector's financial problems. The other factor is the macroeconomic conditions and the stage in the business cycle on which the fiscal effectiveness of taxes and the costs of borrowing and of servicing local debt depend.

The trends and stages marking the development of the theory of fiscal federalism, fiscal institutions and intergovernmental fiscal relations are covered in the literature. An overview of the first and second generations of the fiscal federalism theory was 
provided by Oates (2005). The early fiscal federalism theory was based on a somewhat naïve assumption that public authorities of all levels act to maximise the welfare of their communities. According to the normative approach, the vertical division of revenues should match the distribution of tasks among territorial communities, and taxes should be assigned to particular levels of government based on their design and economic consequences (Musgrave and Musgrave, 1980; Tiebout, 1956; Spahn, 1993; Hockley, 1970).

A milestone in the creation of a more realistic, normative perception of fiscal decentralisation was the formulation of the public choice theory. As well as accounting for the role of political processes, the theory also states that because decision-makers and politicians are opportunists who seek to retain power, control and the high earnings of the administration, they maximise rather than optimise public budgets (Brenan and Buchanan, 1980; Buchanan, 1987).

This view set the stage for numerous discussions and studies on 'soft' and 'hard' financial restrictions and central government bailouts of defaulting local governments. Rarely, however, have these problems been investigated in terms of macroeconomic circumstances, which are hardly predictable and practically uncontrollable by local and central governments. The situation changed after the global financial crisis of 2007-2008, when it was realised how many consequences it had for local finances (IEB, 2009).

\section{Post-crisis Trends in Research}

Most studies examining the sensitivity of public revenues to economic fluctuations look at the state budget (McGranahan and Mattoon, 2012). The number of studies on the cyclicality of tax revenues is also considerable (Kodrzycki, 2014; Alesina et al., 1997; Alesina and Tabellini, 2005; Barro, 1979). Recent studies and analyses point out that the variability and cyclicity of public revenues have been generally higher in the last several decades, meaning that the recession years 2008-2009 were not special in that respect (Kodrzycki and Zhao, 2015). Conventionally, the focus of studies investigating the issue of local finances is on the magnitude of governments' financial autonomy and independence, as well as on the effectiveness in organising the delivery and financing of local public goods. The role and responsibilities of the central government in predicting and averting local crises are also studied (Honadle, 2003; Modlin, 2010).

The global financial crisis and the ensuing recession affected local governments in most countries. Research has shown that the damage they caused depended on countries' structural and institutional environments (Ahmad et al., 2016; Krueathep, 2013). In the wake of the 2008-2009 financial crisis, more attention was also paid to the influence of local finances on the rising deficits of general government sectors. A recent study confirmed that greater fiscal autonomy involves stricter budgetary discipline (Asatryan et al., 2015). 
Many studies on local fiscal crises have investigated the influence of fiscal regulations, political institutions and the budget process on the occurrence of revenue shocks. Rattsø (2003) studied local financial shocks caused by local authorities' limited control over their revenues and few possibilities of reducing spending in the short term for Norway's centralized system. His research showed that central government is, to a large extent, responsible for supporting local budgets, as local authorities have few instruments for responding to revenue shocks. The scarcity of shock-handling options has adverse consequences for local public investments, which are the main cost item affected by shocks. The Norwegian experience implies that preventing the occurrence of local financial crises is possible but not easy, because local governments operate in a highly volatile environment. A major role in triggering local fiscal crises is attributed to various exogenous factors, such as cuts in general and specific grants from central government (Carmichael and Midwinter, 1999).

The macroeconomic determinants of decentralisation drew the attention of Drummond and Mansoor (2003), who studied fiscal policy coordination problems in the framework of a system where revenues and expenditures are decentralised and local authorities can take on debt. Their study confirmed that in such systems the effectiveness of fiscal policy is influenced by institutional solutions.

Spanish economists García-Sánchez et al. (2012) analysed models used to assess the probability of local governments being affected by a financial crisis in the framework of the model of Kloha et al. (2005) and the study of Zafra-Gómez et al. (2009), revealing both advantages and disadvantages of absolute and relative early warning models. The studies were inspired by the financial crises and bankruptcies of towns and cities in the 1970s. Interest in this field of research was renewed with the global crisis of 2008, which also affected local governments. Mechanisms warning against financial problems before they swell into a massive financial and social crisis are indispensable because crises force central governments to financially support local authorities and diminish the revenues they need for carrying out their tasks. A survey of municipalities in the US state of Pennsylvania found that, ceteris paribus, larger intergovernmental grants, lower spending on administration, higher debt levels and lower rates of revenue growth were associated with a higher risk of a fiscal crisis (Trussel and Patrick, 2009). That substantial intergovernmental grants can exacerbate an existing local fiscal crisis or increase the probability of a future crisis was reported as early as the 1970s (Faith, 1979). Solé-Ollé and Sorribas-Navarro (2011) stress, however, that much depends on the adopted institutional solutions. Their study showed that local authorities' limited fiscal autonomy and moral hazards mean that own revenues are less important than general grants in mitigating local fiscal crises.

The financial balance and stability of local governments can be affected by many different risks, factors and circumstances. Rodríguez-Bolívar et al. (2016) analysed them 
for Spanish municipalities and concluded that both demographic factors and financial factors (the net budget result) were important. An analysis of major relationships between the socio-economic factors and the incidence of financial instability and bankruptcies in Italian regions showed that the probability of a financial crisis developing in a local government unit can be partly assessed based on factors such as the level of regional GDP, the density of population and per capita income (Capalbo and Grossi, 2014). The authors of an earlier study on German Länder (NUTS 1 according to EU classification) also reported that inter-Land differences in public debt levels and spending policies were largely determined by the different economic performance of the Länder, while the political orientation of the regional authorities was relatively inconsequential (Seitz, 2000).

Hou and Seligman (2015) analysed three recessions from the years 1985-2009 to determine their effect on local government revenues. The study showed that the introduction of the sales tax in the USA increased fluctuations in public revenues, in contrast to the property tax, which proved to be a relatively steady source of local income. Moreover, the authors established that bond issues during the recession, the rising number of leasing contracts and the local unemployment rate were significantly related to the increasing volatility of public revenues. The recession was also found to change the financial situation of local authorities significantly.

A study of selected US counties showed that capital spending cuts and a reduction in investment activity during and after the recession are the main consequences of a financial crisis (Afonso, 2014). Practice shows that austerity is the preferred instrument for dealing with budget deficits, but it comes with long-term consequences such as there having to be greater expenditures in the future to maintain obsolete infrastructure or to carry out overhauls and repairs, higher interest rates after the recession, and development and economic growth suffering from non-investment. Raising external capital during the recession can be considerably less expensive than when the economic cycle is turning up. A basic analysis and estimation of the revenues of the US state of Massachusetts showed that the irresponsible financial policy in the 1990s and economic downturn were only partly responsible for the fiscal crisis and deep cuts in public service spending (Braunstein, 2004), because around half of the revenue decrease should be attributed to the reduction of effective tax rates and laws diminishing public revenues.

The existence of dependencies between the stability of revenues, the diversity of their sources and the financial situation of local government units was reported by Yan (2011), who looked at the diversity and stability of revenues in terms of the local economic base. Yan concluded that the benefits of diversified revenue sources were ambiguous and that whether the diversity of revenues contributed to their stability depended on the local economic base. If the paramount goal of local financial policy is to ensure a steady flow 
of revenues, the decision about diversification should be made based on the perceived (in)stability of the economic base.

An interesting questionnaire survey was conducted in the US state of Michigan to determine how the state's residents perceived various responses to a fiscal crisis and a reduction in local services (Elling et al., 2013). The results need to be interpreted in terms of Peterson's theory, which states that local councils and officials have limited possibilities of adjusting their development strategies and financial policies to a crisis situation because the main problem is external economic and business conditions that they cannot control (Peterson, 1981; Kemmet, 2003).

The need to diversify revenue streams is less emphasised in the context of local governments than it is with respect to financial markets and investment portfolios, but this aspect of local finances has been analysed too (Carroll et al., 2003). A review of the relevant publications shows that most concentrate on selected aspects of this problem and only a few seek to evaluate the sensitivity of the overall local financial system and the main types of revenue to GDP fluctuations. This study has been designed with a view to filling this research gap. It also presents econometric tools that can be effectively used when the available data series are relatively short.

\section{Research Methodology}

Below, the sensitivity of the main types of local government revenue to GDP fluctuations is assessed for the entire self-government sector in Poland and by the level of government (municipalities, counties and towns with a county status, and voivodeships (NUTS-2 units)). The analysis focuses on revenues that are vital for local governments' fiscal and spending autonomy, namely:

- own revenues, including shared taxes (PIT and CIT) and local taxes,

- transfers from the state budget (general grants and specific grants).

The analysis is performed on data sourced from Poland's Central Statistical Office (Local Data Bank $\rightarrow$ Data, domains $\rightarrow$ Public finance $\rightarrow$ Revenues of ...) and on Eurostat data ('GDP and main components'), spanning the period from 1999 (when counties became the third element of the hitherto two-tier administrative division of the country) to 2016. The symbols of variables representing types of local revenues are shown in Table 1.

In preparation for the analysis, the annual values of GDP (PLN millions, current prices) and the annual values (PLN millions) of all variables in Table 1 were adjusted by a price deflator $(1999=100)$ and, following common practice, were logarithmised to smooth them out. The analysis omitted municipal revenues that had little importance 
from the fiscal point of view, as well as county revenues from CIT because of the too short time series.

To test whether the variables were stationary, the augmented Dickey-Fuller (ADF) test and the Kwiatkowski-Phillips-Schmidt-Shin (KPSS) test were carried out. In all cases when different results were obtained, the differences were resolved by the generalised DickeyFuller test (ADF-GLS). A maximum lag order of 3 was selected for the ADF and ADF-GLS tests based on the indication of the Gretl software. The null hypotheses for the ADF and ADF-GLS tests assumed that a unit root was present, and the alternative hypotheses stated otherwise. The null hypothesis and the alternative hypothesis for the KPSS test assumed, respectively, that a time series was/was not generated by a stationary process.

Table 1: Variables used in the Study and their Symbols

\begin{tabular}{l|c|c|c|c|c}
\hline $\begin{array}{l}\text { Types } \\
\text { of revenues }\end{array}$ & $\begin{array}{c}\text { Self- } \\
\text { govern- } \\
\text { ment } \\
\text { sector }\end{array}$ & $\begin{array}{c}\text { Municipali- } \\
\text { ties without } \\
\text { towns with } \\
\text { county status }\end{array}$ & $\begin{array}{c}\text { Towns } \\
\text { with } \\
\text { county } \\
\text { status }\end{array}$ & Counties & $\begin{array}{c}\text { Voivode- } \\
\text { ships }\end{array}$ \\
\hline Total revenues & $t r$ & $m_{-} t r$ & $t_{-} t r$ & $c_{-} t r$ & $v_{-} t r$ \\
\hline Own revenues & $o r$ & $m_{-} o r$ & $t_{-} o r$ & $c_{-} o r$ & $v_{-} o r$ \\
\hline Shares of personal income tax & $p i t$ & $m_{-} p i t$ & $t_{-} p i t$ & $c_{-} p i t$ & $v_{-} p i t$ \\
\hline Shares of corporate income tax & $c i t$ & $m_{-} c i t$ & $t_{-} c i t$ & $t . s . t . s$. & $v_{-} c i t$ \\
\hline Property tax & - & $m_{-} p t$ & $t_{-} p t$ & - & - \\
\hline Agricultural tax & - & $m_{-} a t$ & $t_{-} a t$ & - & - \\
\hline Specific grants & $s g$ & $m_{-} s g$ & $t_{-} s g$ & $c_{-} s g$ & $v_{-} s g$ \\
\hline General grants & $g g$ & $m_{-} g g$ & $t_{-} g g$ & $c_{-} g g$ & $v_{-} g g$ \\
\hline
\end{tabular}

Notes: t.s.t.s. means 'too short time series'.

Source: Created by the author.

Figure 1 in the Appendix shows that a stochastic trend is present in most data series. The high probability of the analysed variables being non-stationary implies that the parameter estimates may be affected by spurious regression. If a time series shows a trend, a non-stationary variable can be differenced $d$ times until its time series becomes stationary. However, models based on detrended data are only capable of capturing short-run relationships, which is a major disadvantage when it comes to identifying long-run relationships, for instance longrun relationships between GDP and LGU revenues associated with the long-run financial stability of LGUs. The high probability that the analysed variables are non-stationary implies that the parameter estimates may be affected by spurious regression, which calls for using non-classical techniques of economic analysis. 
In the case of non-stationary series, the long-run relationships that we seek here can be analysed by means of a vector error correction model (VEC) of the following general form (Johansen, 1995):

$$
\Delta \boldsymbol{x}_{t}=\Psi_{0} \boldsymbol{d}_{t}+\Pi \boldsymbol{x}_{t-1}+\sum_{i=1}^{k-1} \Pi_{i} \Delta \boldsymbol{x}_{t-i}+\xi_{t}, \quad t=1,2, \ldots, \mathrm{T}
$$

where:

$x_{t}=\left[x_{1 t}, x_{2 t}, \ldots, x_{n t}\right]^{\prime}$ is the vector of endogenous variables,

$\Delta$ is the first difference of the variable $x_{t}$,

$\boldsymbol{d}_{\mathrm{t}}$ is a vector with deterministic elements (a trend term, zero-one variables, etc.),

$\Psi_{0}$ is the matrix of parameters of the vector $\boldsymbol{d}_{t}$,

$\boldsymbol{\Pi}=\Sigma_{j=i+1}^{k} \mathbf{A}_{i}-\mathbf{1}$ is the matrix of coefficients representing the effects of short-run adjustments and the long-run cointegrating relationships,

$\mathbf{A}_{i}$ are the matrices of parameters on the lagged variables of the vector $\boldsymbol{x}_{t}$ (without zero elements),

$\Pi_{i}=-\Sigma_{j=i+1}^{k} \mathbf{A}_{j}$ is the matrix of autoregression coefficients,

$\xi \quad$ is white noise.

The VEC model is a transformed vector autoregression model (VAR), which is generally written as (Lütkepohl, 1993, 9-10):

$$
\boldsymbol{x}_{t}=\boldsymbol{A}_{0} \boldsymbol{d}_{t}+\sum_{i=1}^{k} \boldsymbol{A}_{\boldsymbol{i}} \boldsymbol{x}_{\boldsymbol{t}-\boldsymbol{i}}+\boldsymbol{e}_{t}, \quad t=1,2, \ldots \mathrm{T},
$$

where: $\boldsymbol{A}_{0}-$ the matrix of parameters of vector $\boldsymbol{d}_{\boldsymbol{t}}, \boldsymbol{e}_{\boldsymbol{t}}-$ a vector of stationary random components.

VEC models do not make the classical distinction between endogenous and exogenous variables, nor do they require zero restrictions to be imposed on the parameters to identify a system of equations. Their main advantage is their ability to reveal both short-run and long-run relationships.

The construction of a VEC model using non-stationary data series should start with the determination of their order of integration. If the data series have the same integration order $(d)$ and their linear combination is stationary, a long-run equilibrium relationship between them is possible (cointegrated variables). In the case of a two-dimensional process (i.e., one containing two non-stationary time series of the same integration order), $r$ can take a value of 0 (no cointegration) or 1 (1 cointegrating vector). The cointegration tests include the Engle-Granger test and/or the Johansen procedure (1991, pp. 1558-1561; 1992, 
pp. 387-394) consisting of the trace test and the maximum eigenvalue test. Before cointegration can be tested, the order of lag $(k)$ must be selected ${ }^{1}$. The order of lag should reflect natural relationships between the variables and prevent autocorrelation of error terms.

In this study, the statistical properties of the models were tested by means of:

- the Doornik-Hansen (D-H) test for the normal distribution of residuals with the following hypotheses:

$H_{0}$ : the residuals have a normal distribution, $H_{1}: \sim H_{0}$.

- the Ljung-Box Q' (L-B) test for error term autocorrelation with the following hypotheses:

$H_{0}$ : the error term is not autocorrelated, $H_{1}: \sim H_{0}$.

- the ARCH effect test with the following hypotheses:

$H_{0}$ : the $\mathrm{ARCH}$ effect is not present, $H_{1}: \sim H_{0}$.

In the section below, the responsiveness of particular types of LGU revenues to GDP changes is measured using the impulse response function (IRF), which shows how endogenous variables react over a specified time horizon to impulses (shocks) that they themselves and other endogenous variables generate. Additionally, the forecast error variance decomposition (FEVD) is performed to determine what percentage of the forecast error variance of a variable is due to other variables and how it changes with forecast length (Lütkepohl, 1993, pp. 56-68).

\section{Results}

The ADF, KPSS and ADF-GLS tests showed that all the variables were non-stationary, but their first differences indicated that only $\Delta m_{-} a t, \Delta c \_o r$ and $\Delta v \_c i t$ did not meet the stationarity requirement (Table 2). As a result, all three variables were omitted from further analysis. Other time series, such as $g d p$, were integrated of order one (in the case of $o r$ and $t \_s g$, the order of integration dependent on the level of significance).

1 The estimation of the lag order (k) and the order of cointegration ( $r$ ) is carried out for the VAR model. With cointegrated time-series, VAR $(\mathrm{k})$ can be used to construct the VEC $(\mathrm{k}-1)$ model. 
Table 2: Stationarity Tests for First Differences

\begin{tabular}{|c|c|c|c|c|}
\hline \multirow[b]{2}{*}{ Variable } & ADF & KPSS & ADF-GLS & \multirow{2}{*}{ Conclusion } \\
\hline & \multicolumn{3}{|c|}{$p$-value } & \\
\hline$\Delta t r$ & 0.14 & $>0.10$ & 0.01 & stationary variable \\
\hline$\Delta o r$ & n. 0 & $>0.10$ & - & stationary variable \\
\hline$\Delta p i t$ & n. 0 & $>0.10$ & - & stationary variable \\
\hline$\Delta c i t$ & 0.01 & $>0.10$ & - & stationary variable \\
\hline$\Delta s g$ & 0.27 & $>0.10$ & 0.09 & $\begin{array}{l}\text { stationary variable (acceptable result of the ADF- } \\
\text { GLS test) }\end{array}$ \\
\hline$\Delta g g$ & 0.19 & $>0.10$ & n. 0 & stationary variable \\
\hline$\Delta m_{-} t r$ & 0.06 & $>0.10$ & n. 0 & stationary variable \\
\hline$\Delta m_{-}$or & n. 0 & $>0.10$ & - & stationary variable \\
\hline$\Delta m \_p i t$ & 0.01 & $>0.10$ & - & stationary variable \\
\hline$\Delta m_{-} c i t$ & 0.01 & $>0.10$ & - & stationary variable \\
\hline$\Delta m \_p t$ & 0.28 & $>0.10$ & n. 0 & stationary variable \\
\hline$\Delta m \_a t$ & 1.00 & $>0.10$ & 0.89 & non-stationary variable \\
\hline$\Delta m \_s g$ & 0.23 & $>0.10$ & 0.02 & stationary variable \\
\hline$\Delta m_{-} g g$ & 0.02 & $>0.10$ & - & stationary variable \\
\hline$\Delta t \_t r$ & 0.15 & $>0.10$ & n. 0 & stationary variable \\
\hline$\Delta t_{-}$or & 0.10 & $>0.10$ & n. 0 & stationary variable \\
\hline$\Delta t \_p i t$ & n. 0 & $>0.10$ & - & stationary variable \\
\hline$\Delta t \_c i t$ & n. 0 & $>0.10$ & - & stationary variable \\
\hline$\Delta t \_p t$ & 0.05 & $>0.10$ & n. 0 & stationary variable \\
\hline$\Delta t \_a t$ & 0.02 & $>0.10$ & - & stationary variable \\
\hline$\Delta t \_s g$ & 0.08 & 0.09 & 0.06 & $\begin{array}{l}\text { stationary variable (acceptable result of the ADF- } \\
\text { GLS test) }\end{array}$ \\
\hline$\Delta t_{-} g g$ & n. 0 & $>0.10$ & - & stationary variable \\
\hline$\Delta c_{-} t r$ & 0.03 & $>0.10$ & - & stationary variable \\
\hline$\Delta c \_$or & 0.18 & $>0.10$ & 0.10 & non-stationary variable \\
\hline$\Delta c \_p i t$ & n. 0 & $>0.10$ & - & stationary variable \\
\hline$\Delta c \_s g$ & n. 0 & $>0.10$ & - & stationary variable \\
\hline$\Delta c_{-} g g$ & n. 0 & $>0.10$ & - & stationary variable \\
\hline$\Delta v_{-} t r$ & n. 0 & $>0.10$ & - & stationary variable \\
\hline$\Delta v_{-}$or & 0.02 & $>0.10$ & - & stationary variable \\
\hline$\Delta v_{-} p i t$ & 0.15 & $>0.10$ & 0.02 & stationary variable \\
\hline$\Delta v_{-}$cit & 0.09 & $>0.10$ & 0.62 & non-stationary variable \\
\hline$\Delta v \_s g$ & 0.05 & $>0.10$ & n. 0 & stationary variable \\
\hline$\Delta v_{-} g g$ & 0.01 & $>0.10$ & - & stationary variable \\
\hline$\Delta g d p$ & 0.77 & $>0.10$ & 0.01 & stationary variable \\
\hline
\end{tabular}

Notes: $\Delta$ is a first difference operator $n .0$ means near 0 . The lag order used in the ADF and ADF-GLS tests based on the Schwarz Info Criterion were: 3 for $\Delta m_{-} p i t, \Delta c_{-} s g, 1$ for $\Delta m_{-} c i t, \Delta m_{-} a t, \Delta t_{-} o r, \Delta t_{-} c i t, \Delta t_{-} a t$, $\Delta c_{-} g g, \Delta v_{-}$pit and 0 in all other cases.

Source: Created by the authors using the Gretl package. 
Table 3: Results of lag order selection and Johansen tests for cointegration

\begin{tabular}{|c|c|c|c|c|c|c|}
\hline \multicolumn{7}{|c|}{ Specification with unrestricted constant } \\
\hline Test & \multicolumn{3}{|c|}{ Lag order } & \multicolumn{3}{|c|}{ Cointegration } \\
\hline & \multicolumn{2}{|c|}{ Information criteria } & \multirow{2}{*}{$\begin{array}{c}\text { Conclusion } \\
\qquad k=\end{array}$} & \multirow{2}{*}{$\begin{array}{c}\text { Maximum } \\
\text { eigenvalue test }\end{array}$} & \multirow{2}{*}{$\begin{array}{c}\text { Trace } \\
\text { test }\end{array}$} & \multirow{2}{*}{$\begin{array}{c}\text { Conclusion } \\
r=\end{array}$} \\
\hline Variable & AIC & BIC & & & & \\
\hline tr & 2 & 2 & 2 & $0 / 1$ & $0 / 1$ & 1 \\
\hline pit & 2 & 1 & 2 & 1 & 1 & 1 \\
\hline cit & 2 & 2 & 2 & $0 / 1$ & $0 / 1$ & 1 \\
\hline$g \boldsymbol{g}$ & 1 & 1 & 1 & 1 & 1 & 1 \\
\hline m_or & 2 & 1 & 2 & 1 & 0 & 1 \\
\hline$m \_p i t$ & 2 & 2 & 2 & 1 & 1 & 1 \\
\hline$m_{-}$cit & 2 & 2 & 2 & 1 & 1 & 1 \\
\hline$m \_p t$ & 2 & 1 & 2 & $0 / 1$ & $0 / 1$ & 1 \\
\hline$m \_g g$ & 2 & 1 & 2 & 1 & 1 & 1 \\
\hline$t \_p t$ & 2 & 2 & 2 & $0 / 1$ & $0 / 1$ & 1 \\
\hline$t$ tat & 2 & 2 & 2 & 1 & 1 & 1 \\
\hline$t \_g g$ & 1 & 1 & 1 & 1 & 1 & 1 \\
\hline c_tr & 2 & 2 & 2 & 1 & 1 & 1 \\
\hline c_sg & 2 & 1 & 1 & 1 & 1 & 1 \\
\hline c_gg & 1 & 1 & 1 & 1 & 1 & 1 \\
\hline v_sg & 1 & 1 & 1 & 1 & 1 & 1 \\
\hline \multicolumn{7}{|c|}{ Specification with unrestricted constant and restricted trend } \\
\hline sg & 2 & 1 & 1 & 0 & $0 / 1$ & 1 \\
\hline$g g$ & 2 & 2 & 2 & 1 & 1 & 1 \\
\hline m_tr & 2 & 2 & 2 & 0 & $0 / 1$ & 1 \\
\hline m_or & 2 & 1 & 2 & $0 / 1$ & $0 / 1$ & 1 \\
\hline m_gg & 2 & 1 & 2 & 1 & 1 & 1 \\
\hline t_tr & 1 & 1 & 1 & 1 & 1 & 1 \\
\hline$t$ tgg & 1 & 1 & 1 & 1 & 1 & 1 \\
\hline c_gg & 1 & 1 & 1 & 1 & 1 & 1 \\
\hline v_pit & 2 & 2 & 2 & 1 & 1 & 1 \\
\hline
\end{tabular}

Notes: If the order of integration is 0 or 1 , one cointegrating relationship is assumed. For different $k$ values produced by AIC and BIC, lag for which a cointegrating relation was found is shown.

Source: Created by the author using the Gretl package. 
In the case of the VEC model, the lags of successive variables included in the model reduce the degrees of freedom. Because the sample only consisted of 18 observations, the sensitivity of particular LGU revenues to economic fluctuations was estimated for pairs of equations made up of GDP and a specific revenue (see Sobel and Holcombe, 1996, pp. 536-540).

Before the models' parameters were estimated, the lag order $k$ was selected and the data series were tested for cointegration. An assumption was made that the lag order for the annual data should not exceed 2. The values of $k$ were selected for each pair of equations using the Akaike Information Criterion (AIC) and the Bayesian Information Criterion (BIC). If they produced different values of $k$, both values were used to test a model.

The time series were tested for cointegration by performing the maximum eigenvalue test and the trace test. Because many variables exhibited trending behaviour (Appendix) and given that the tests proposed by Johansen are sensitive to model specification, the tests were conducted with an unrestricted constant and with an unrestricted constant and a restricted trend (Johansen, 1995).

The analysis showed that, in 2004, the share of local government revenues from PIT and CIT rapidly expanded after the introduction of the act on local government income (Act of 13 November 2003). The act noticeably increased municipalities' and counties' revenues from PIT and voivodeships' revenues from CIT. Consequently, the equations for both types of revenue were tested allowing for a zero-one variable for the years 1999-2003.

The results presented in Table 3 concern variables that, according to the testing results, have a long-run equilibrium relationship with GDP.

Time series cointegrated with GDP were then used to build VEC models, which are capable of capturing both short-run and long-run relationships between variables. The parameter estimates for particular equations are shown in Table 4. ec1 represents an error correction element the values of which should range from -1 to 0 . The closer its value is to -1 , the faster the variable returns to long-run equilibrium. 
Table 4: Estimation results of VEC models

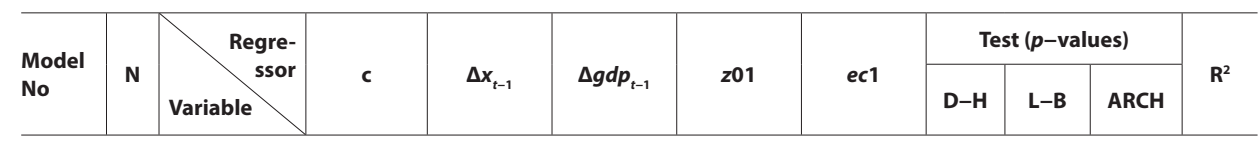

Models with unrestricted constant

\begin{tabular}{|c|c|c|c|c|c|c|c|c|c|c|c|}
\hline \multirow{2}{*}{ I } & \multirow{6}{*}{16} & $\Delta t r$ & $-5.11^{* *}$ & $0.68^{* *}$ & 0.46 & - & $-0.82^{* *}$ & \multirow{2}{*}{0.81} & 0.32 & 0.20 & 0.55 \\
\hline & & $\Delta g d p$ & 0.37 & 0.09 & 0.19 & - & 0.06 & & 0.55 & 0.83 & 0.18 \\
\hline \multirow{2}{*}{ II } & & $\Delta p i t$ & $-10.10^{*}$ & 0.36 & 2.99 & - & $-0.57^{*}$ & \multirow{2}{*}{0.28} & 0.59 & 0.76 & 0.33 \\
\hline & & $\Delta g d p$ & 0.63 & 0.01 & 0.14 & - & 0.03 & & 0.68 & 0.59 & 0.17 \\
\hline \multirow{2}{*}{ III } & & $\Delta c i t$ & $6.57^{* * *}$ & $-0.10^{*}$ & $4.81^{* * *}$ & $-1.72^{* * *}$ & $-0.95^{* * *}$ & \multirow{2}{*}{0.46} & 0.87 & 0.58 & 0.98 \\
\hline & & $\Delta g d p$ & 0.09 & 0.00 & 0.33 & -0.03 & -0.01 & & 0.39 & 0.51 & 0.28 \\
\hline \multirow{2}{*}{ IV } & \multirow{2}{*}{17} & $\Delta g g$ & $1.7^{* * *}$ & - & - & - & $-0.64^{* * *}$ & \multirow{2}{*}{0.97} & 0.75 & 0.30 & 0.54 \\
\hline & & $\Delta g d p$ & 0.19 & - & - & - & -0.06 & & 0.24 & 0.84 & 0.04 \\
\hline \multirow{2}{*}{ v } & \multirow{2}{*}{16} & $\Delta m_{-} o r$ & $-5.70^{* * * *}$ & -0.03 & $2.01^{*}$ & - & $-0.71^{* * *}$ & \multirow{2}{*}{0.90} & 0.72 & 0.64 & 0.64 \\
\hline & & $\Delta g d p$ & -0.76 & 0.04 & 0.21 & - & -0.1 & & 0.48 & 0.21 & 0.29 \\
\hline \multirow{2}{*}{ VI } & \multirow{12}{*}{16} & $\Delta m \_p i t$ & -13.68 & 0.15 & 4.02 & - & -0.81 & \multirow{2}{*}{0.98} & 0.84 & 0.31 & 0.67 \\
\hline & & $\Delta g d p$ & -0.75 & 0.02 & 0.34 & - & -0.05 & & 0.51 & 0.28 & 0.22 \\
\hline \multirow{2}{*}{ VII } & & $\Delta m_{-} c i t$ & $1.32^{* * *}$ & -0.14 & $5.01^{* *}$ & $-0.44^{* * *}$ & $-0.51^{* * *}$ & \multirow{2}{*}{0.77} & 0.34 & 0.06 & 0.88 \\
\hline & & $\Delta g d p$ & $0.09^{*}$ & -0.03 & $0.55^{*}$ & $-0.22^{* *}$ & $-0.03^{*}$ & & 0.38 & 0.58 & 0.56 \\
\hline \multirow{2}{*}{ VIII } & & $\Delta m_{-} p t$ & $-1.53^{* * *}$ & 0.06 & -0.81 & - & $-0.65^{* * *}$ & \multirow{2}{*}{0.78} & 0.07 & 0.49 & 0.69 \\
\hline & & $\Delta g d p$ & 0.29 & -0.05 & 0.41 & - & 0.11 & & 0.74 & 0.15 & 0.35 \\
\hline \multirow{2}{*}{ IX } & & $\Delta m_{-} g g$ & $0.91^{* * *}$ & 0.27 & 0.05 & - & $-0.76^{* * *}$ & \multirow{2}{*}{0.40} & 0.41 & 0.55 & 0.75 \\
\hline & & $\Delta g d p$ & -0.18 & -0.04 & 0.49 & - & 0.17 & & 0.46 & 0.31 & 0.26 \\
\hline \multirow{2}{*}{$x$} & & $\Delta t \_p t$ & $-1.16^{* * *}$ & $0.24^{*}$ & $-0.90^{*}$ & - & $-0.46^{* * *}$ & \multirow{2}{*}{0.49} & 0.11 & 0.22 & 0.87 \\
\hline & & $\Delta g d p$ & $0.22^{* *}$ & 0.02 & 0.38 & - & $0.07^{* *}$ & & 0.85 & 0.15 & 0.37 \\
\hline \multirow{2}{*}{$\mathbf{X I}$} & & $\Delta t \_a t$ & $-14.3^{* * *}$ & $0.79^{* * *}$ & $4.05^{*}$ & - & $-1.21^{* * *}$ & \multirow[t]{2}{*}{0.93} & 0.72 & 0.26 & 0.80 \\
\hline & & $\Delta g d p$ & $0.52^{*}$ & -0.03 & 0.34 & - & 0.04 & & 0.75 & 0.84 & 0.33 \\
\hline \multirow{2}{*}{ XII } & \multirow{2}{*}{17} & $\Delta t_{-} s g$ & $0.86^{* * *}$ & - & - & - & $-0.59 * * *$ & \multirow{2}{*}{0.01} & 0.57 & 0.24 & 0.44 \\
\hline & & $\Delta g d p$ & 0.12 & - & - & - & -0.06 & & 0.34 & 0.59 & 0.07 \\
\hline & & $\Delta c_{-} t r$ & $-1.63^{* * *}$ & 0.64 & $-0.39 * * *$ & - & $-0.80^{* * *}$ & & 0.83 & 0.70 & 0.70 \\
\hline XIII & & $\Delta g d p$ & -0.18 & 0.03 & 0.09 & - & -0.11 & 0.02 & 0.93 & 0.91 & 0.29 \\
\hline & 0 & $\Delta c \_s g$ & $6.83^{* *}$ & $0.66^{* *}$ & -0.41 & - & $-0.36^{* *}$ & & 0.13 & 0.98 & 0.51 \\
\hline Niv & & $\Delta g d p$ & $0.95^{* *}$ & 0.01 & -0.07 & - & $-0.05^{* *}$ & 0.10 & 0.95 & 0.28 & 0.49 \\
\hline
\end{tabular}


Table 4: (Continuation)

\begin{tabular}{|c|c|c|c|c|c|c|c|c|c|c|c|}
\hline \multirow{2}{*}{$\begin{array}{l}\text { Model } \\
\text { No }\end{array}$} & \multirow[b]{2}{*}{$\mathbf{N}$} & \multirow{2}{*}{$\begin{array}{r}\text { Regre- } \\
\text { ssor } \\
\text { Variable }\end{array}$} & \multirow[b]{2}{*}{ c } & \multirow[b]{2}{*}{$\Delta x_{t-1}$} & \multirow[b]{2}{*}{$\Delta g d p_{t-1}$} & \multirow[b]{2}{*}{$z 01$} & \multirow[b]{2}{*}{ ec1 } & \multicolumn{3}{|c|}{ Test ( $p$-values) } & \multirow[b]{2}{*}{$\mathbf{R}^{2}$} \\
\hline & & & & & & & & D-H & L-B & ARCH & \\
\hline \multicolumn{12}{|c|}{ Models with unrestricted constant } \\
\hline \multirow{2}{*}{$\mathbf{x v}$} & \multirow{4}{*}{17} & $\Delta c \_g g$ & $1.89^{* * *}$ & - & - & - & $-0.90 * * *$ & \multirow{2}{*}{0.17} & 0.11 & 0.08 & 0.62 \\
\hline & & $\Delta g d p$ & $0.26^{* *}$ & - & - & - & $-0.11^{*}$ & & 0.49 & 0.87 & 0.22 \\
\hline \multirow{2}{*}{ XVI } & & $\Delta v \_s g$ & $9.73^{* * *}$ & - & - & - & $-0.77^{* * *}$ & \multirow{2}{*}{0.49} & 0.97 & 0.50 & 0.38 \\
\hline & & $\Delta g d p$ & $0.41^{* *}$ & - & - & - & $-0.03^{* *}$ & & 0.67 & 0.33 & 0.29 \\
\hline
\end{tabular}

Models with unrestricted constant and restricted trend

\begin{tabular}{|c|c|c|c|c|c|c|c|c|c|c|c|}
\hline \multirow{2}{*}{ XVII } & \multirow{2}{*}{17} & $\Delta s g$ & $12.19^{*}$ & - & - & - & $-0.40^{*}$ & \multirow{2}{*}{0.19} & 0.82 & 0.99 & 0.20 \\
\hline & & $\Delta g d p$ & 0.55 & - & - & - & -0.02 & & 0.23 & 0.55 & 0.04 \\
\hline \multirow{2}{*}{ XVIII } & \multirow{10}{*}{16} & $\Delta g g$ & $-13.72^{* * *}$ & -0.11 & $-1.43^{* *}$ & - & $-0.97^{* * *}$ & \multirow{2}{*}{0.05} & 0.40 & 0.96 & 0.80 \\
\hline & & $\Delta g d p$ & $3.23^{*}$ & 0.03 & $0.86^{* *}$ & - & $0.23^{*}$ & & 0.39 & 0.61 & 0.32 \\
\hline \multirow{2}{*}{ XIX } & & $\Delta m_{-} t r$ & $6.73^{* * *}$ & 0.10 & $1.66^{*}$ & - & $-0.67^{* * *}$ & \multirow{2}{*}{0.51} & 0.31 & 0.28 & 0.55 \\
\hline & & $\Delta g d p$ & 1.06 & $0.20^{* *}$ & 0.16 & - & -0.10 & & 0.59 & 0.28 & 0.42 \\
\hline \multirow{2}{*}{$x x$} & & $\Delta m \_o r$ & $5.57^{* * *}$ & -0.07 & $2.60^{* *}$ & - & $-0.60 * * *$ & & 0.53 & 0.13 & 0.65 \\
\hline & & $\Delta g d p$ & $0.92^{*}$ & $0.03^{* *}$ & 0.29 & - & $-0.10^{*}$ & 0.97 & 0.60 & 0.16 & 0.38 \\
\hline \multirow{2}{*}{ XXI } & & $\Delta m \_p i t$ & $12.81^{* * *}$ & 0.02 & $5.37^{* * *}$ & - & $-0.65^{* * *}$ & \multirow{2}{*}{0.94} & 0.39 & 0.55 & 0.74 \\
\hline & & $\Delta g d p$ & 0.89 & 0.01 & 0.45 & - & -0.04 & & 0.58 & 0.25 & 0.27 \\
\hline \multirow{2}{*}{ XXII } & & $\Delta m \_g g$ & $-4.49^{* * *}$ & 0.15 & -0.22 & - & $-0.70^{* * *}$ & \multirow{2}{*}{0.15} & 0.42 & 0.69 & 0.78 \\
\hline & & $\Delta g d p$ & $1.25^{*}$ & -0.01 & $0.60^{*}$ & - & $0.19 *$ & & 0.60 & 0.21 & 0.34 \\
\hline \multirow{2}{*}{ XXIII } & \multirow{6}{*}{17} & $\Delta t_{-} t r$ & -2.33 & - & - & - & -0.32 & \multirow{2}{*}{0.17} & 0.81 & 0.24 & 0.12 \\
\hline & & $\Delta g d p$ & $1.15^{* *}$ & - & - & - & $0.15^{* *}$ & & 0.85 & 0.42 & 0.33 \\
\hline \multirow{2}{*}{ XXIV } & & $\Delta t \_g g$ & $2.60^{* * *}$ & - & - & - & $-0.59 * * *$ & \multirow{2}{*}{0.03} & 0.50 & 0.29 & 0.42 \\
\hline & & $\Delta g d p$ & 0.34 & - & - & - & -0.07 & & 0.38 & 0.51 & 0.08 \\
\hline \multirow{2}{*}{$x x v$} & & $\Delta c \_g g$ & $-15.09 * * *$ & - & - & - & $-0.99 * * *$ & \multirow{2}{*}{0.71} & 0.67 & 0.43 & 0.80 \\
\hline & & $\Delta g d p$ & -1.14 & - & - & - & -0.08 & & 0.34 & 0.94 & 0.12 \\
\hline \multirow{2}{*}{ XXVI } & \multirow{2}{*}{16} & $\Delta v \_p i t$ & $8.34^{* * *}$ & $0.36^{*}$ & $1.93^{*}$ & - & $-0.51 * * *$ & \multirow{2}{*}{0.64} & 0.93 & 0.40 & 0.69 \\
\hline & & $\Delta g d p$ & 0.84 & 0.07 & 0.31 & - & -0.05 & & 0.58 & 0.20 & 0.25 \\
\hline
\end{tabular}

Notes: $\mathrm{N}$ - number of observations, c - intercept, $x_{t-1}$ - variable representing LGU revenues, $z 01$ - zero-one variable, ec1 - error correction parameter, $\mathrm{R}^{2}$ - coefficient of determination. ${ }^{* * *}$ and ${ }^{* * *}$ denote levels of significance according to Student's test, respectively $0.1,0.05$ and 0.01 . Student's t-statistics is not the best tool for assessing the significance of estimates because of the high probability of collinearity of variables in autoregressive models. The L-B test shows $p$-values for the first order autocorrelation. Source: Created by the author using the Gretl package. 
Let us note, however, that if the error correction parameter is $<-1$ or $>0$, the system does not return to the long-run equilibrium path after it has deviated from it. In the case of $\Delta t a t$, the parameter was -1.21 , so it was removed from further analysis. The presence of $e c 1>0$ in some GDP equations can be explained by specification errors (e.g., the omission of some vital explanatory variables, etc.), but the equations are dropped from analysis as unrelated to the main purpose of the study. Furthermore, the fact that the roots of the characteristic equation of each of the other systems of equations in Table 4 are inside the unit circle implies the stability of relationships presented in Table 4 . The $p$-values calculated for models XII, XVIII and XXIV indicate that the null hypotheses can be rejected in favour of the alternative hypotheses stating that residuals do not have normal distributions. The autocorrelation tests did not find correlations between the successive values of residuals, but in the case of $\Delta m p t$, the presence of autocorrelation was determined by the level of significance. The test statistics did not show that variance clustering was present in the equations, but in the case of $\Delta m_{-}$cit and $\Delta c$ gg , the existence of the ARCH effect depended, again, on the level of significance. As regards variables $\Delta m_{-} o r, \Delta m \_p i t, \Delta m \_g g$ and $\Delta c \_g g$, further analysis was performed on the systems of equations with better statistical properties (XX, VI, IX and XXV, respectively).

In the next step, VEC models that passed statistical testing were used to construct impulse response functions (IRFs) to measure the magnitude of changes in different types of LGU revenues induced by GDP variations. The IRFs were orthogonalised using a Cholesky decomposition. The y-axes of the charts in Figure 2 in the Appendix show the response of LGUs revenues to a unit change in the standard deviation of GDP residuals and the $\mathrm{x}$-axes represent time in years.

The IRF plots in Figure 2 show different responses of LGUs to changes in GDP. For instance, a positive impulse from GDP increases the total revenues of the self-government sector as a whole, with the largest change occurring in the third year after the impulse.

The greatest sensitivity to fluctuations in GDP is shown by the local shares of income taxes. They change the most in the second year after the impulse.

The property tax collected by municipalities and towns with a county status is basically insensitive to changes in GDP. The IRF values for this tax are close to zero almost throughout the forecast period.

At the level of the self-government sector, specific grants and GDP are inversely related to each other: a positive GDP impulse increasingly reduces their amount. In counties and voivodeships, a positive change in GDP significantly reduces the level of specific grants, especially in the first year following its occurrence.

The curves representing municipalities', counties' and the self-government sector's revenues from general grants are similar, showing that their sensitivity to fluctuations in the economy is very low. 
Table 5 shows the extent to which the forecast error variance of the main types of LGU revenues is explained by GDP. As can be seen, its changes account for much of the variance in total revenues of the LGU sector (33\% in the $1^{\text {st }}$ year of analysis and $91 \%$ in the $10^{\text {th }}$ year). Moreover, GDP fluctuations largely contribute to the variable amounts of revenues from PIT and CIT in the LGU sector as a whole and in municipalities, as well as affecting the voivodeships' revenues from PIT. At the same time, their limited role in explaining variations in revenues from the property tax in municipalities and towns with a county status leads to a conclusion that these levels of government can rely on the tax as a source of funding.

Table 5: FEVD values for LGU revenues over a 10-year horizon (\% of LGU revenue variance due to GDP)

\begin{tabular}{|c|c|c|c|c|c|c|c|c|c|c|}
\hline Years & 1 & 2 & 3 & 4 & 5 & 6 & 7 & 8 & 9 & 10 \\
\hline tr & 33 & 65 & 79 & 85 & 87 & 88 & 89 & 90 & 91 & 91 \\
\hline pit & 62 & 78 & 83 & 85 & 86 & 86 & 87 & 87 & 88 & 88 \\
\hline cit & 46 & 72 & 73 & 73 & 73 & 73 & 73 & 73 & 73 & 73 \\
\hline $\boldsymbol{g g}$ & 20 & 18 & 22 & 28 & 34 & 39 & 44 & 48 & 51 & 54 \\
\hline sg & 0 & 1 & 1 & 2 & 3 & 5 & 6 & 7 & 8 & 9 \\
\hline$m \_t r$ & 2 & 25 & 29 & 30 & 29 & 30 & 30 & 31 & 30 & 30 \\
\hline m_or & 1 & 34 & 41 & 41 & 41 & 42 & 42 & 42 & 42 & 42 \\
\hline m_pit & 26 & 69 & 78 & 77 & 76 & 76 & 77 & 78 & 78 & 79 \\
\hline m_cit & 1 & 30 & 44 & 47 & 47 & 48 & 48 & 48 & 48 & 48 \\
\hline$m \_p t$ & 11 & 15 & 16 & 24 & 33 & 39 & 43 & 46 & 48 & 50 \\
\hline $\boldsymbol{m} \_g \boldsymbol{g}$ & 15 & 12 & 12 & 15 & 19 & 23 & 28 & 32 & 35 & 39 \\
\hline$t$ t_tr & 15 & 19 & 22 & 25 & 27 & 29 & 31 & 32 & 33 & 34 \\
\hline$t$ t_pt & 0 & 5 & 6 & 9 & 20 & 32 & 40 & 45 & 49 & 52 \\
\hline c_tr & 2 & 1 & 7 & 19 & 26 & 29 & 31 & 32 & 34 & 37 \\
\hline C_sg & 11 & 13 & 15 & 16 & 16 & 16 & 16 & 16 & 16 & 16 \\
\hline C_gg & 7 & 39 & 58 & 68 & 74 & 78 & 81 & 83 & 85 & 86 \\
\hline$v_{-}$pit & 30 & 54 & 60 & 60 & 62 & 67 & 71 & 72 & 71 & 71 \\
\hline$v \_s g$ & 12 & 12 & 12 & 12 & 12 & 13 & 13 & 13 & 13 & 13 \\
\hline
\end{tabular}

Source: Created by the author using the Gretl package. 


\section{Discussion and Conclusions}

Financial crises reduce the financial independence of local governments. The analysis has shown, however, that the main types of revenues of the Polish LGU sector as a whole and of its particular tiers respond to economic fluctuations with different sensitivity. A major source of local revenues in Poland is the shares of income taxes (PIT and CIT) that have the formal status of own revenues. The local ownership of these revenues is, however, strongly questioned based on the argument that municipalities, counties and voivodeships have no influence on how the taxes are designed, nor do they directly control revenues from them. Another weakness of shared taxes revealed by this research is their sensitivity to changes in GDP.

As far as the sustainability of local revenues is concerned, the property tax as a local source and general grants as an external source of funding are crucial. However, the fiscal situation of the general government sector and thereby the finances of local governments are affected by the financial constraints resulting from deep recessions that come with globalisation, which makes economies and public sectors increasingly vulnerable to external shocks. During economic crises, local revenues sensitive to GDP fluctuations may entail hard budget restrictions. This provides an argument for diversifying their sources of revenues, as each of them has a slightly different responsiveness to shocks.

This study has demonstrated that a comprehensive view of local government finances can identify structural gaps in intergovernmental fiscal relations that escape conventional analysis. The advantage of the proposed research methodology is that it can be applied to study relatively short times periods (given the length of economic cycles) for all countries and revenue systems. The problem of short data series is common in quantitative studies on local finances, because of the frequent changes to systems, reforms and (de) centralisation processes. 


\section{Appendix}

Figure 1: Time series (logs)
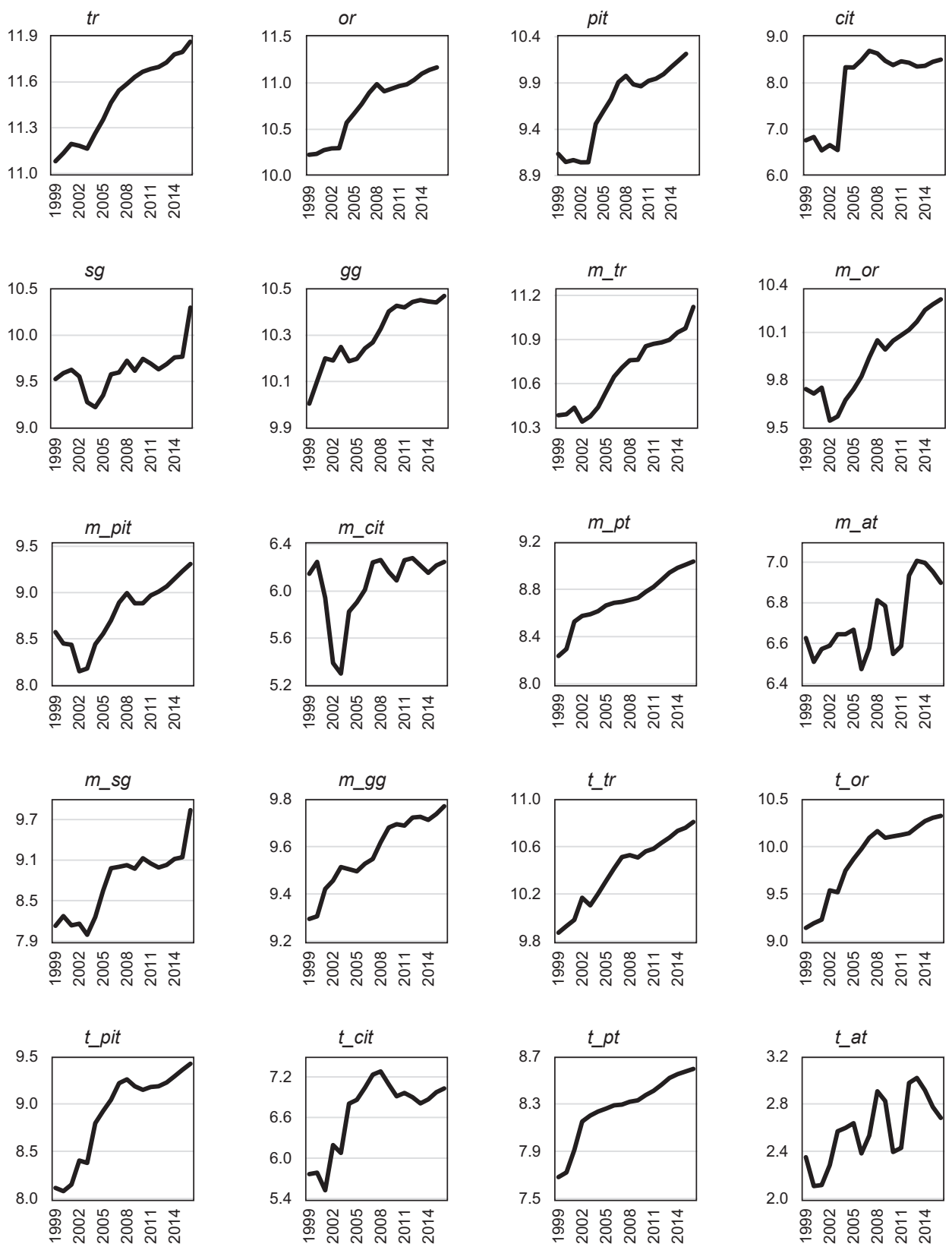
Figure 1: (Continuation)
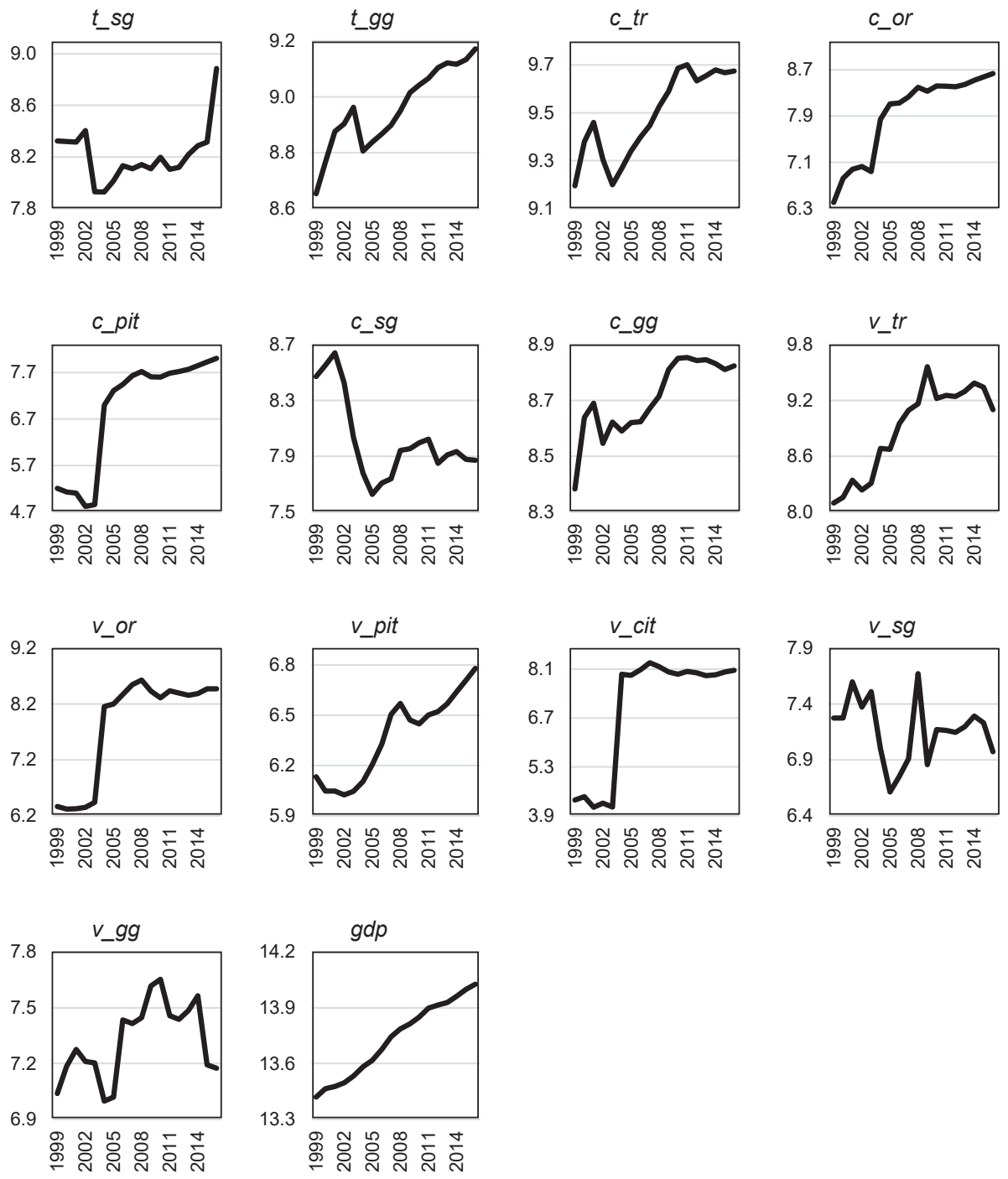

Source: Central Statistical Office, Eurostat 
Figure 2: Ten-year response of LGU revenues to an impulse from GDP

$\operatorname{tr}$

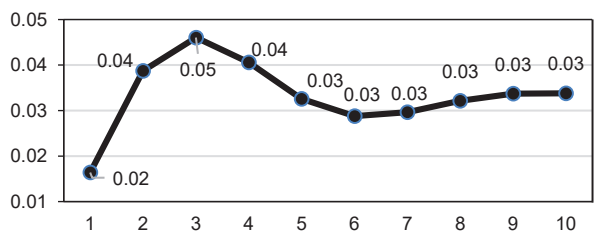

cit

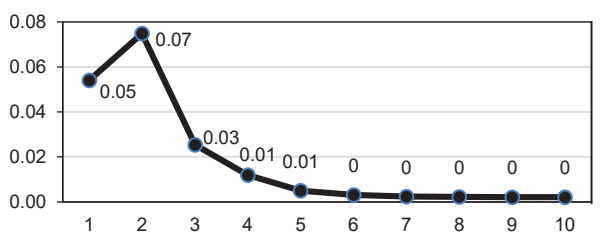

$g g$

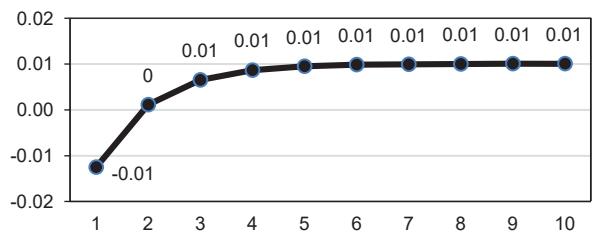

m_or

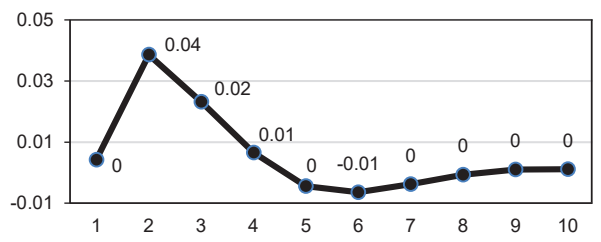

m_cit

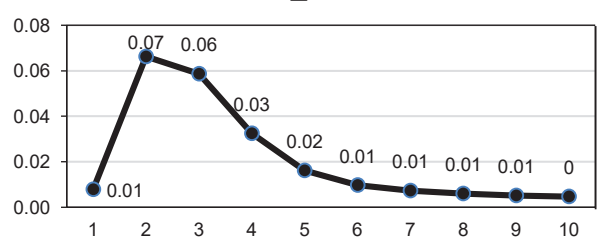

pit

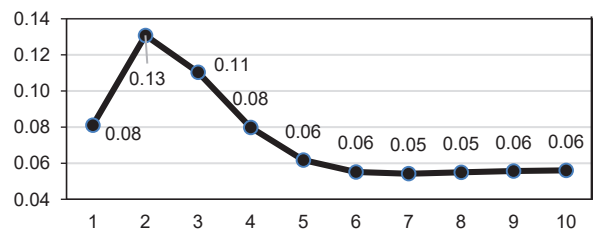

$s g$

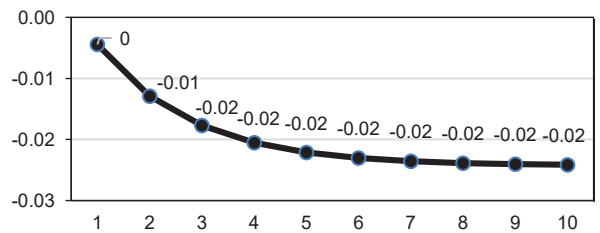

m_tr

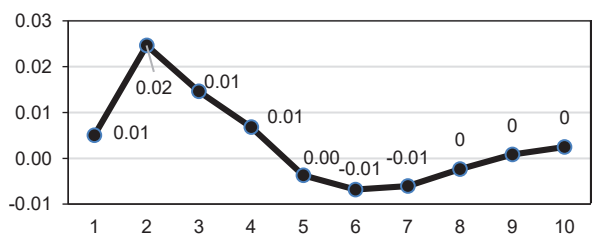

$m \_p i t$

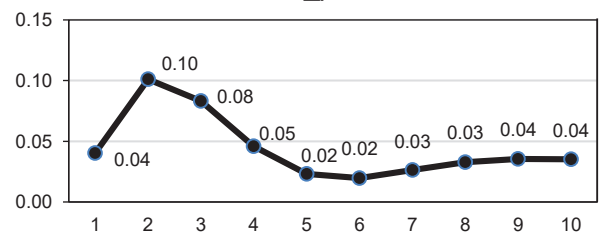

$m \_p t$

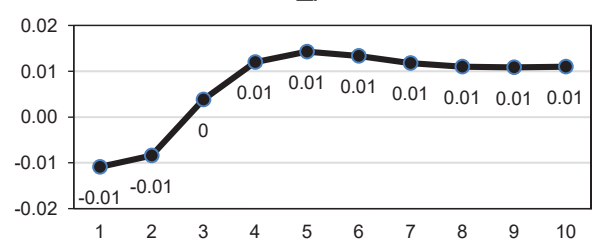


Figure 2: (Continuation)
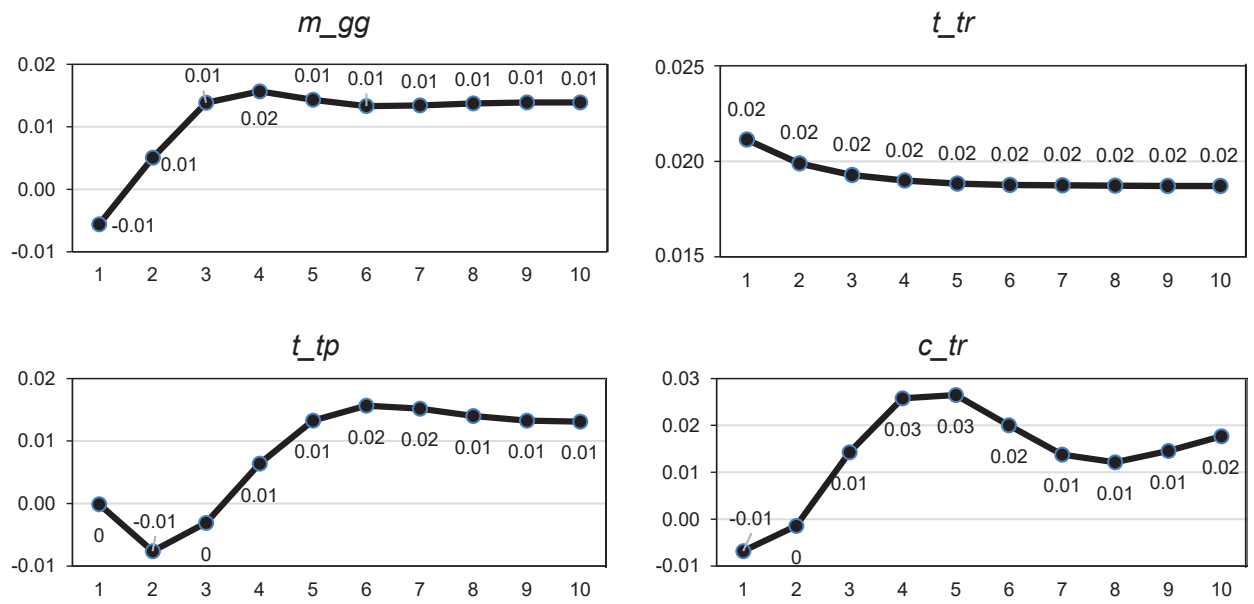

\section{C_sg}

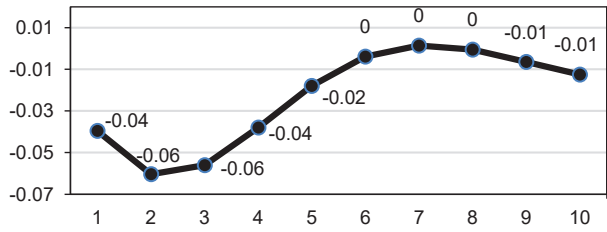

C_gg

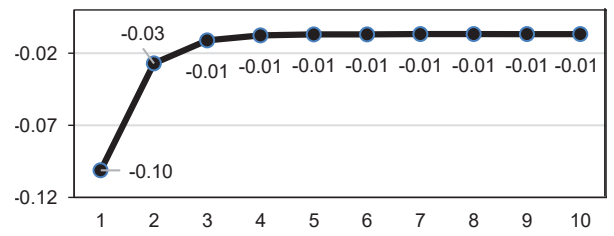

v_pit

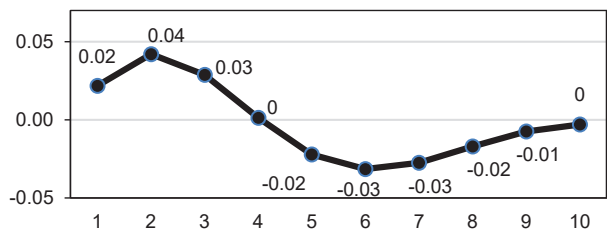

V_sg

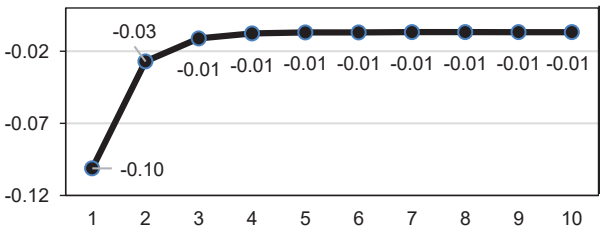

Source: Authors. 


\section{References}

Afonso, W. B. (2014). Local Government Capital Spending During and After Recessions: A Cause for Concern? International Journal of Public Administration, 37(8), 494-505, https://doi.org/ 10.1080/01900692.2013.865646

Ahmad, E., Brosio, G. eds. (2015). Handbook of Multilevel Finance. Cheltenham: Edward Elgar Publishing. ISBN 9780857932280.

Alesina, A., Roubini, N., Cohen, G. D. (1997). Political Cycles and the Macroeconomy. Cambridge MA: MIT Press. ISBN 9780262011617.

Alesina, A., Tabellini, G. (2005). Why is Fiscal Policy often Procyclical? NBER. Cambridge, MA Working Paper No. 11600, https://doi.org/10.3386/w11600

Asatryan, Z., Feld, L. P., Geys, B. (2015). Partial Fiscal Decentralization and Sub-national Government Fiscal Discipline: Empirical Evidence from OECD Countries. Public Choice, 163(3-4), 307-320, https://doi.org/10.1007/s11127-015-0250-2

Barro, R. J. (1997). On the Determination of the Public Debt. Journal of Political Economy, 87(5), 940-971.

Braunstein, E. (2004). What Caused the Massachusetts Fiscal Crisis? Challenge, 47(4), 17-40, https://doi.org/10.1080/05775132.2004.11034257

Brennan, G., Buchanan, J. M. (1980). The Power to Tax: Analytical Foundations of a Fiscal Constitution. Cambridge: Cambridge University Press. ISBN 978-0521233293.

Buchanan, J. M. (1987). Public Finance in Democratic Process. Fiscal Institutions and Individual Choice. New York: The University of North Carolina Press. ISBN 978-0807841907.

Canova, F. (1995). Vector Autoregressive Models: Specification, estimation, inference and Forecasting, in Pesaran, H., Wiekens, M., eds., Handbook of Applied Econometrics. Oxford: Blackwell.

Capalbo, E., Grossi, G. (2014). Assessing the Influence of Socioeconomic Drivers on Italian Municipal Financial Destabilization. Public Money \& Management, 34(2), 107-114, https://doi.org/10.1080/09540962.2014.887518

Carmichael, P., Midwinter, A. (1999). Glasgow: Anatomy of a Fiscal Crisis. Local Government Studies, 25(1), 84-98, https://doi.org/10.1080/03003939908433939

Carroll, D. A., Eger, R. J. III, Marlowe, J. (2003). Managing Local Intergovernmental Revenues: The Imperative of Diversification, International Journal of Public Administration, 26(13), 1495-1518, https://doi.org/10.1081/PAD-120024407

Drummond, P., Mansoor, A. (2003). Macroeconomic Management and the Devolution of Fiscal Powers. Emerging Markets Finance and Trade, 39(1), 63-85, https://doi.org/10.1080/15404 96x.2003.11052529

Elling, R., Krawczyk, K., Carr, J. (2014). What Should We Do? Public Attitudes about How Local Government Officials Should Confront Fiscal Stress, Local Government Studies, 40(3), 380-402, https://doi.org/10.1080/03003930.2013.823408

Faith, R. L. (1979). Local Fiscal Crises and Intergovernmental Grants: A Suggested Hypothesis. Public Choice, 34(3-4), 317-331, https://doi.org/10.1007/bf00225672 
García-Sánchez, I. M., Cuadrado-Ballesteros, B., Frías-Aceituno, J. V., Mordan, N. (2012). A New Predictor of Local Financial Distress, International Journal of Public Administration, 35(11), 739-748, https://doi.org/10.1080/01900692.2012.679173

Hockley, G. C. (1970). Monetary Policy and Public Finance. London: Routledge \& Kegan Paul Ltd. Honadle, B.W. (2003). The States' Role in U.S. Local Government Fiscal Crises: A Theoretical Model and Results of a National Survey, International Journal of Public Administration, 26(13), 1431-1472, https://doi.org/10.1081/PAD-120024405

Hou, Y., Seligman, J. S. (2010). Lost Stability? Consumption Taxes and the Cyclical Variability of State and Local Revenues. John Glenn School of Public Affairs. Working Paper Series, https://doi. org/10.2139/ssrn.1029697

IEB (2009). IEB's World Report on Fiscal Federalism'09. 2009, Institut d'Economia de Barcelona (IEB), Barcelona, December 2009.

Johansen, S. (1991). Estimation and Hypothesis Testing of Cointegration Vectors in Gaussian Vector Autoregressive Models, Econometrica, 59(6), 1551-1580, https://doi. org/10.2307/2938278

Johansen, S. (1992). Determination of Cointegration Rank in the Presence of a Linear Trend. Oxford Bulletin of Economics and Statistics, 54(3), 383-397, https://doi. org/10.1111/j.1468-0084.1992.tb00008.x

Johansen, S. (1995). Likelihood-Based Inference in Cointegrated Vector Autoregressive Models. Oxford: Oxford University Press. ISBN 9780198774501.

Kemmet, L. (2003). Local Fiscal Stress in California: Out of Local Control and Driving Toward Growth, International Journal of Public Administration, 26(13), 1473-1494, https://doi.org/10.1081/PAD-120024406

Kloha, P., Weissert, C. S., Kleine, R. (2005). Developing and testing a composite model to predict local fiscal distress, Public Administration Review, 65(3), 313-323, https://doi.org/10.1111/j.1540-6210.2005.00456.x

Kodrzycki, Y. K. (2014). Smoothing State Tax Revenues over the Business Cycle: Gauging Fiscal Needs and Opportunities. Federal Reserve Bank of Boston. Available at: http://www. bostonfed.org/economic/wp/index.htm

Kodrzycki, Y. K., Zhao, B. (2015). Achieving Greater Fiscal Stability: Guidance for the New England States. New England Public Policy Center Research Report No. 15-2, https://doi.org/10.2139/ssrn.2671800

Krueathep, W. (2013). Municipal Responses to Fiscal Austerity: The Thai Case, International Journal of Public Administration, 36(7), 453-468, https://doi.org/10.1080/01900692.2013 .772631

Law of November 13, 2003 on Local Government Revenues. Journal of Laws No. 203, item 1966]

McGranahan, L., Mattoon, R. H. (2002). State Tax Revenues over the Business Cycle: Patterns and Policy Responses. The Federal Reserve Bank of Chicago. Chicago Fed Letter, Essays of Issues No. 299. 
Modin, S. (2010). Rationalizing the Local Government Decision-Making Process. Public Performance \& Management Review, 33(4), 571-593, https://doi.org/10.2753/ pmr1530-9576330403

Musgrave, R. A., Musgrave, P. B. (1980). Public Finance in Theory and Practice. Third Edition, New York: McGraw-Hill Book Company.

Navarro-Galera, A., Rodríguez-Bolívar, M.P., Alcaide-Muñoz, L., María Deseada López-Subires, M. D. (2016). Measuring the Financial Sustainability and its Influential Factors in Local Governments. Applied Economics, 48(41), 3961-3975, https://doi.org/10.1080/00036846 .2016 .1148260

Oates, W. E. (2005). Toward a Second-generation Theory of Fiscal Federalism. International Tax and Public Finance, 12(4), 349-373, https://doi.org/10.1007/s10797-005-1619-9

Peterson, P. (1981). City limits. Chicago: The University of Chicago Press. ISBN 9780226662930.

Rattsø, J. (2003). Fiscal Adjustment under Centralized Federalism: Empirical Evaluation of the Response to Budgetary Shocks. Department of Economics, Norwegian University of Science and Technology, https://doi.org/10.1628/0015221041525750

Setiz, H. (2000). Fiscal Policy, Deficits and Politics of Subnational Governments: The Case of the German Laender. Public Choice, 102, 183-218.

Sims, C. A. (1980). Macroeconomics and Reality. Econometrica, 48(1), 1-48, https://doi. org/10.2307/1912017

Sobel, R. S., Holcombe, R. G. (1996). Measuring the Growth and Variability of Tax Bases over the Business Cycle. National Tax Journal, 49(4), 535-552.

Solé-Ollé, A., Sorribas-Navarro, P. (2011). The Dynamic Adjustment of Local Government Budgets: Does Spain Behave Differently? Applied Economics, 44(25), 3203-3213, https://doi.org/10.1080/00036846.2011.570723

Spahn, B. (1993). The Design of Federal Fiscal Constitutions in Theory and in Practice. European Economy Reports and Studies No. 5.

Tiebout, C. (1956). A Pure Theory of Local Expenditure. Journal of Political Economy, 64(5), 416-424, https://doi.org/10.1086/257839

Trussel, J. M., Patrick, P. A. (2009). A Predictive Model of Fiscal Distress in Local Governments. Journal of Public Budgeting, Accounting \& Financial Management, 21(4), 578-616, https://doi.org/10.1108/jpbafm-21-04-2009-b004

Yan, W. (2011). The Interactive Effect of Revenue Diversification and Economic Base on US Local Government Revenue Stability. Public Money \& Management, 31 (6), 419-426, https://doi.org/10.1080/09540962.2011.618766

Zafra-Gomez, J. S., López-Hernández, A. M., Hernández-Bastida, A. (2009). Developing an Alert System for Local Governments in Financial Crisis. Public Money \& Management, 29(3), 175-181, https://doi.org/10.1080/09540960902891731 